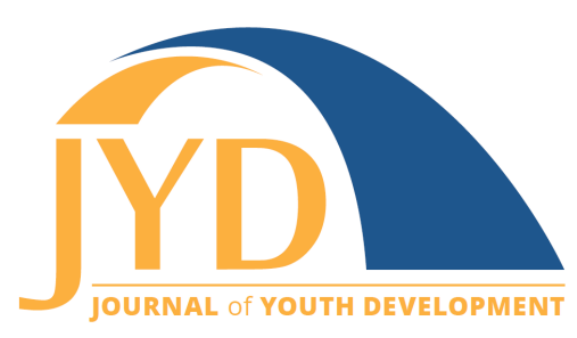

http://jyd.pitt.edu/ | Vol. 16 Issue 5 DOI 10.5195/jyd.2021.916 | ISSN 2325-4017 (online)

\title{
Book Review: Changemakers! Practitioners Advance Equity and Access in Out-of-School Time Programs
}

\author{
April Riordan \\ Independent Consultant \\ aprilriordan@gmail.com
}

\begin{abstract}
Changemakers! Practitioners Advance Equity and Access in Out-of-School Time Programs, edited by Sara Hill and Femi Vance (Information Age) provides a thorough (and long overdue) examination of youth development policy and practice in the context of White supremacy, systemic oppression, and other forms of inequity. It offers a valuable introduction for those new to the field and for veterans just now starting to consider more equitable approaches to their work.
\end{abstract}

Key words: equity, access, out-of-school time, youth development, youth workers, youth development professionals

Changemakers! Practitioners Advance Equity and Access in Out-of-School Time Programs (Hill \& Vance, 2019) is a thorough (and long overdue) examination of youth development policy and practice in the context of White supremacy, systemic oppression, and other forms of inequity. In its preface, Sarah Zeller-Berkman recalls her first job as a youth worker; she writes, "This is a book I needed back then . . . a roadmap to changing unjust systems" (p. x). As a fellow longtime youth work professional, I agree.

The experiences and ideas shared in this book will not be new to every reader. Many youth programs and youth work practitioners have been doing this work, in partnership with young people, for a long time. But this book can offer a valuable introduction for those new to the field and for veterans just now starting to consider more equitable approaches to their work. It may also help to lend credibility for those working to advance changes to promote access and equity in their programs.

\section{(cc) $\mathrm{Br}$} New articles in this journal are licensed under a Creative Commons Attribution 4.0 License. This journal is published by the University Library System, University of Pittsburgh and is cosponsored by the University of Pittsburgh Press. The Journal of Youth Development is the official peer-reviewed publication of the National Association of Extension 4-H Youth Development Professionals and the National AfterSchool Association. 
Organized into two sections, the first section is focused on organizational policies and procedures that impact access and equity. The second section is focused on how program quality and staff preparation impact young people's experiences in out-of-school time (OST) opportunities. Each chapter is presented from the perspective of youth workers and community leaders working directly with youth. Each chapter ends with reflections from researchers, including questions for further exploration. Throughout the book, terminology is noted and defined at the bottom of the page to clarify readers' understanding of complex topics.

For me, the best chapters were those that provided clear and specific examples of system and program-level changes. In Chapter 2, Ken Anthony outlines guidelines for developing and sustaining successful school-community partnerships, sharing highlights and challenges from his work in Connecticut communities. This chapter helped me diagnose problems I have experienced in leading school-based OST programs-notably how "the imbalance of power between school and afterschool programs" can lead to a "lack of recognition of expertise on the part of school personnel towards afterschool staff" (Hill \& Vance, 2019, p. 35). I would recommend this chapter to anyone currently navigating, or about to develop, an OST partnership with schools, and encourage practitioners to make every effort to share it with school principals.

In Chapter 3, Rachel Loeper delivers one truth after another while sharing the missteps and corrections she has made with her OST writing program located in a historically Black neighborhood in Philadelphia. This is the first time I have seen someone lay out so clearly the connections between outreach efforts and systemic racism. In one of my favorite examples, she writes about the problematic practice of short enrollment periods and limited slots: "This kind of set up primarily serves the donors, who want to be able to track a cohort and play 'savior' to a specific group of kids" (Hill \& Vance, 2019, p. 50).

Chapter 5 is one of the few chapters written by a person from a marginalized or minoritized community. Suzanne Stolz addresses inclusion of youth with disabilities in OST programs, sharing her own experiences as a disabled young person and outlining strength-based approaches for doing inclusion better. Writing about an inclusive philosophy, she encourages programs to ask themselves, "Do we view disability as a problem or as a natural aspect of humanity? Are people disabled by the limits of their bodies and minds or by the physical and social barriers in their environments?" (Hill \& Vance, 2019, p. 81). Stolz advises that our answers to these questions inform our philosophy toward inclusion. This asset-based and human-centered approach added to the reality that adaptations that accommodate one's 
disability almost always benefit both the disabled and the nondisabled participants. As such, this chapter outlines a model not just for inclusion of youth with disabilities but a universal model for inclusion, period.

Chapter 6 includes deeply personal stories from Merle McGee's life and youth work career that set the context for the importance of developing critical youth development practices that grow the ability of both marginalized and privileged youth to navigate discussions around identity, power, privilege, and oppression and provide opportunities to leverage those skills in pursuit of social justice. I believe critical youth development is the future of youth development practice. Practitioners, leaders, and funders all need to know what this work looks and feels like when done right, and this chapter is a compelling argument to invest training, time, and dollars into supporting organizations ready to engage in this work.

There are several other chapters in the book that will resonate with some readers more than others. The first chapter provides an overview of implicit bias in youth development with a heavy focus on "legacy" organizations like 4-H and scouting. Chapter 4 breaks down the paternalism inherent in youth program funding. Chapter 7 focuses on micro, meso, and macro levels of community response to unique needs of boys and young men of color. The final chapter is about a museum's efforts to engage their immigrant neighbors in museum programming, highlighting the importance of including parents and extended family in outreach and programming.

I would like to have seen a chapter about how an organization evolved to better meet the needs of LGBTQ youth, more recognition of intersectionality, and more authors representing marginalized and minoritized communities (including young people themselves). But overall, I found it valuable to read the book and appreciated that it presents ideas that are both promising and problematic, and as such, raises meaningful questions for our field that, I hope, ignite urgency, and spur action.

Because of our diverse lived experiences and varying levels of critical consciousness, every reader will engage with the content differently-and because we are all constantly evolving in our ways of thinking, our individual experience with it will change every time we read it as well. I first read the book and drafted this review in late 2019, before the pandemic and before George Floyd was murdered by Minneapolis police just one mile from my front door.

My original conclusion included some encouraging words about how hard "this work" can be and about having the courage to try new things. All this time later those closing words feel 
empty, though I am sure they were sincere back then. Interestingly, many of the questions the book raised for me remained the same over time, but I feel much less trepidation today about asking them. Can our existing organizations, particularly legacy organizations, dismantle White supremacy and re-emerge as leaders of critical youth development field? Or do we need to leave some of our programs and practices behind to make space for community-led solutions? Can we train our way out of oppressive systems? Or do we need to find ways to move faster to bring about the kind of change our kids and communities deserve?

\section{For Further Reading}

\section{Recommended by the Book Review Author}

Back when I was a 23-year-old youth worker, I was fortunate to find Martin Brokenleg's work, Reclaiming Youth at Risk: Our Hope for the Future (Brendtro et al., 2019). This book, first published in 1990, advocates a strength-based and trauma-informed perspective. To learn more about critical youth development, I recommend Torie Weiston-Serdan's (2017) book, Critical Mentoring: A Practical Guide and the online community, Reimaqining Youth Work.

Theresa Ferrari, the section editor for JYD's resource reviews, has compiled a list of other volumes in the Current Issues in Out-of-School Time series and reviews of those volumes that have appeared in past issues of JYD. You can find this information in the Appendix.

\section{References}

Brendtro, L. K., Brokenleg, M., \& Van Bockern, S. (2019). Reclaiming youth at risk: Our hope for the future ( $3^{\text {rd }}$ ed.). Solution Tree.

Hill, S., \& Vance, F. (Eds.). (2019). Changemakers! Practitioners advance equity and access in out-ofschool time programs. Information Age.

Weiston-Sherdan, T. (2017). Critical mentoring: A practical guide. Stylus. 


\section{Appendix \\ Resource Review Section Editor's Note}

Listed below are the additional volumes in the Current Issues in Out-of-School Time series and the corresponding reviews that appear in past issues of the Journal of Youth Development.

- Malone, H. J., \& Donahue, T. (Eds.) (2017). The growing out-of-school time field: Past, present, and future. Information Age Publishing.

- Walker, J. A. (2018). The growing out-of-school time field: Past, present, and future. Journal of Youth Development, 13(4), 190-192. (https://doi.org/10.5195/jyd.2018.724)

- Delaney, E., \& Moroney, D. A. (Eds.). (2018). Social and emotional learning in out-ofschool time: Foundations and futures. Information Age Publishing.

- Gannon, T. N. (2019). Book review: Social and emotional learning in out-ofschool-time: Foundations and futures. Journal of Youth Development, 14(3), 222-225. (https://doi.org/10.5195/jyd.2019.862)

- Brion-Miesels, G., Tseming, J., \& Vasudevan, D. S. (Eds.). (2020). At our best: Building youth-adult partnerships in out-of-school time settings. Information Age Publishing.

- Ross, L. (2021). Book review: At our best: Building youth-adult partnerships in out-of-school time. Journal of Youth Development, 16(1), 150-152.

(https://doi.org/10.5195/jyd.2021.1092)

- Russell, C. A., \& Newhouse, C. (Eds.). (2021). Measure, use, improve! Data use in outof-school time settings. Information Age Publishing.

- Toomey, M. M. (2021). Book review: Measure, use, improve! Data use in out-ofschool time. Journal of Youth Development, 16(1), 153-155.

(https://doi.org/10.5195/jyd.2021.1093)

Theresa Ferrari

Ohio 4-H Youth Development, Ohio State University Extension ferrari8@osu.edu 